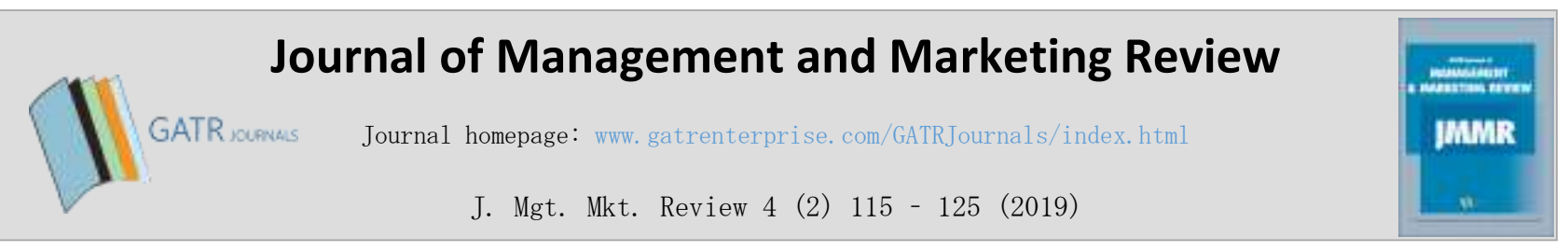

\title{
How Commitment, Satisfaction, and Cost Fluctuations Influence Customer Loyalty
}

\author{
Andreas Samudro, ${ }^{1 *}$ Ujang Sumarwan, $^{2}$ Megawati Simanjuntak, ${ }^{2}$ Eva Z Yusuf ${ }^{1}$ \\ ${ }^{1}$ Graduate School of Management and Business, Bogor Agricultural University, Indonesia \\ ${ }^{2}$ Department of Family and Consumer Science, Graduate School of Management and Business, Bogor Agricultural University, \\ Indonesia
}

\begin{abstract}
Objective - The purpose of this study is to investigate which factors have a stronger influence on final purchase decisions from the perspective of the chemical market. The factors under consideration are customer satisfaction, commitment and cost fluctuations.

Methodology/Technique - By understanding the factors that influence purchase decisions, a chemical company or other industrial company can place greater focus on the factors that will improve or enhance customer loyalty. The research design is a conclusive-descriptive and quantitative method.

Findings \& Novelty - The results of the analysis confirm that customer commitment and satisfaction have a stronger influence on customer loyalty, compared to fluctuating costs. Satisfaction does not have a direct influence on loyalty, except where commitment is used as a mediator.

Type of Paper: Empirical

Keywords: Satisfaction; Commitment; Switching Cost; Loyalty; B2B Relationship.

Reference to this paper should be made as follows: Samudro, A.; Sumarwan, U.; Simanjuntak, M.; Yusuf, E. Z. (2019). How Commitment, Satisfaction, and Cost Fluctuations Influence Customer Loyalty, J. Mgt. Mkt. Review, 4 (2): 115 125 https://doi.org/10.35609/jmmr.2019.4.2(3)
\end{abstract}

JEL Classification: M10, M12, M19, M30.

\section{Introduction}

Customer loyalty is a crucial goal for every company to ensure their sustainability in a highly competitive market (Lam, Shankar, Erramilli, \& Murthy, 2004; Rauyruen \& Miller, 2007; Rust, Zeithaml, \& Lemon, 2000). Repeat purchases is a manifestation of customer loyalty; hence, the factors influencing customer loyalty are important to understand. What factors directly affect customer loyalty? Is customer satisfaction enough to increase customer loyalty, or is further effort needed? These questions are answered in the present research. The presence or absence of these factor can have a positive or negative effect on customer loyalty (Russo, Confente, Gligor, \& Autry, 2015).

Many previous studies have identified commitment as an antecedent of loyalty (Doney \& Cannon, 1997).

* Paper Info: Revised: March 05, 2019

Accepted: June 19, 2019

* Corresponding author: Andreas Samudro

E-mail: unang1968@gmail.com

Affiliation: Graduate School of Management and Business, Bogor Agricultural University, Indonesia 
Commitment is an important construct, which is at the center of the relationship quality theory (Hunt \& Morgan, 1994). Satisfaction and commitment are two basic predictors of loyalty (Ulaga \& Eggert, 2006; Walter, Mueller, \& Helfert, 2000). Some scholars define commitment as a direct antecedent of loyalty, whilst others consider satisfaction to be a direct antecedent of loyalty. Satisfaction refers to a customer's judgment toward a vendor's performance (Oliver \& DeSarbo, 1988) and the customer's judgment based on past experience (Fournier \& Mick, 1999). Both of these definitions have more rational and cognitive thinking toward satisfaction. From this, it is clear that the construct of loyalty consists of satisfaction, commitment and loyalty. Switching cost is defined as an important avenue for predicting customer retention (Anderson, 1994; Anderson \& Sullivan, 1993). From a practical view, switching cost is used as a tactic to encourage repeat purchases or customer loyalty (Bendapudi \& Berry, 1997; Fornell, 1992). In a previous B2B study, switching costs is defined as the customer's perception of the additional costs required to conclude the relationship and secure an alternative (Blut, Frennea, Mittal, \& Mothersbaugh, 2015; Yanamandram \& White, 2006). In essence, switching costs is as an important determinant of loyalty (Blut et. al., 2015). This empirical study investigates all of the factors influencing loyalty, focusing on some crucial constructs: satisfaction, commitment, loyalty and switching costs.

\section{Theoretical Framework}

Oliver and DeSarbo (1988) state that satisfaction refers to the customer's judgment toward a vendor's performance. Meanwhile, other scholars define satisfaction as the customer's judgment based on experience, which involves an emotional assessment (Anderson, Fornell, \& Lehmann, 1994; Fournier \& Mick, 1999). Both of these definitions take a rational and cognitive approach toward satisfaction. In research on mixed industries populations, Gil-Saura, Frasquet-Deltoro and Cervera-Taulet (2009) conclude that satisfaction positively influences loyalty. Some researchers conclude that satisfaction has a positive influence on loyalty (Molinari, Abratt, \& Dion, 2008). However, industrial purchasing decisions are also driven by emotions or an affective approach (Borg \& Johnston, 2013; Kadic-Maglajlic, Vida, Obadia, \& Plank, 2016). Satisfaction also has a direct and positive influence on commitment (Palaima \& Auruškevičiene, 2007; Sanchez-Franco, 2009).

Commitment is the willingness of each party to continue interacting each other (Storbacka, Strandvik, \& Gronroos, 1994) and is an essential factor in a successful relationship (Walter et. al., 2000). Many previous studies define commitment as an intention to develop and maintain a long-term relationship. Loyalty is an essential objective in an industrial relationship and is commonly referred to as vendor loyalty (Dick \& Basu, 1994). In the turbulence of a business environment, customer loyalty is the most important consideration (Barroso \& Picón, 2012). Some scholars identify loyalty from different dimensions: a behavioral dimension and an attitudinal dimension. From a behavioral dimension, loyalty refers to a customer's willingness to repurchase a product and/or service with the same provider (Rauyruen \& Miller, 2007). Meanwhile, the attitudinal dimension refers to loyalty as a buyer's commitment to a product, service, brand, or organization (Briggs, Landry, \& Daugherty, 2007). Oliver (1993) defines loyalty from a broader spectrum of attitudinal, behavioral, and cognitive dimensions: loyalty is a deep willingness to repurchase a product and/or service from the same vendor. Loyalty is a sequence of cognitive processes, affective processes, conative processes and action (Oliver, 1999). As purchase decisions in a B2B setting are more complex than in a B2C setting, it is reasonable to expect that B2B switching cost is more important than B2C switching cost (Blut et. al., 2015). Further complex study of the factors influencing customer loyalty by comparing switching costloyalty path with others constructs such as satisfaction-loyalty, commitment-loyalty. Switching costs is an important strategy to increase customer loyalty (Jones, Reynolds, Mothersbaugh, \& Beatty, 2007). There are three categories of switching costs: procedural, relational and financial (Blut et. al., 2015; Samudro, Sumarwan, Yusuf, \& Simanjuntak, 2018). In this paper, switching costs reflects these categories. 


\section{Conceptual Framework and Hypotheses}

Commitment has three dimensions: input, attitudinal and temporal (Gundlach, Achrol, \& Mentzer, 1995). The dimensions of input commitment consist of idiosyncratic and dedicated investment for instance: custom products, dedicated $R \& D$ projects and custom training for customer service teams. Attitudinal aspects of commitment identifies a participant's intention to contribute to long-term investment; the idiosyncratic investments made by each party increasing each party's commitment (Anderson \& Weitz, 1992). The temporal dimension indicates short-term input commitment to contribute to future output. In the chemical market, custom made products work in the early period of relationship; a firm adjusts and develops custom chemical formulations for specific prospects and/or customers. This commitment input works temporarily until the product trial is complete, after which the attitudinal aspect of commitment is needed to maintain the relationship in the future. Firms emphasize long-term benefits rather than short-term attractive alternatives; commitments lead to the success of the long term relationship (Morgan \& Hunt, 1994).

H1: Commitment has a positive influence on customer loyalty.

Many scholars estimate the positive relationship between satisfaction and loyalty (Askariazad \& Babakhani, 2015; Biedenbach, Bengtsson, \& Marell, 2015; Blut, Beatty, Evanschitzky, \& Brock, 2014; Watson, Beck, Henderson, \& Palmatier, 2015). Customers tend to become attached to those organizations with a good track record of satisfactory delivery of products and/or services; hence, satisfaction has a positive influence on loyalty (Fullerton, 2011). Some previous studies state that industrial buying is driven by logic, tests, and facts; it tends to be a more cognitive approach (Kemp, Borders, Anaza, \& Johnston, 2018; Patti, Hartley, \& Kennedy, 1991). This concept fits to the business practice of the chemical market, which is initiated by a sequence of quality and application tests prior to the establishment of a business.

H2: Satisfaction has a positive influence on customer loyalty.

Caceres and Paparoidamis (2007) conclude that satisfaction has a positive influence on commitment. In the chemical market, service and products are dimensions of customer perceived quality. Patti et. al. (1991) and Kemp et. al. (2018) state that industrial buying is driven by logic, tests, and facts. These concepts seem to fit the business practice of the chemical market. With the strict product trials and review of consistent product quality, it takes time to successfully achieve customer loyalty. All satisfaction-commitment and satisfactionloyalty concepts have lead to the present study which aims to investigate the relationship between the various constructs. Some previous studies have investigated the post-purchase factors as determinants of repeat purchase decisions (Bolton \& Drew, 1991; Oliver \& DeSarbo, 1988). A satisfactory experience with a product and/or service appear to be a crucial requirement for business continuity and repeat purchases (Oliver, 1993). As for experience, there is a small time delay during which the customer consumes and evaluates the product and/or services which may lead to loyalty. In other words, satisfaction will not influence loyalty directly, only where commitment is a mediator.

H3: Satisfaction has a positive influence on customer commitment.

As a general stand point, switching costs is the perceived economic and psychological costs associated with the replacement of existing suppliers by other alternatives (Anderson, 1994; Maute \& Forrester, 1993). This concept has a broader spectrum of switching costs than the economical based switching cost definition; the buyer's perspective refers to the economical and psychological approaches. This empirical study combines the economical and psychological approaches, since the chemical market requires a lot of work with new alternatives products and services. This new product application requires workers to make a necessary adjustment in the way they complete their work requiring a necessary post switching behavior to 
adapt and respond to new procedures. This change of routine triggers psychological resistance and burden upon workers. Sellers invest in switching costs to strengthen customer relationships (Blut et. al., 2015). It is a common practice for the chemical industry to have specific investments, for instance, in machines and equipment (Blut et. al., 2015). This investment can be a barrier for customers to move to alternative suppliers. Hence, switching costs is recognized as a tactic to retain customers.

H4: Switching costs has a positive influence on customer loyalty.

\section{Research Method}

\subsection{Research design and data collection}

The research design is conclusively descriptive, with a literature review as the initial step, studying each latent variable, and the connections among the variables, which leads to the development of an initial model. The hypotheses are designed to identify the relationship between the constructs for further investigation. The author conducted a pre-test by sending questionnaires to 30 respondents. The research questionnaires are also validated by a professional peer review (Carmine \& Zeller, 1979). The unit analysis of the research vary: $\mathrm{MDF} /$ medium density fibre board, particle board, plywood and others relating to the plywood industry such as block board, bare core, laminated panel, film face, wood decking, parquet flooring, and furniture. This study uses census techniques with a total industry of 164 companies 105 of which are used as the units for analysis in the research. Every company (unit analysis) contributed two to four questionnaires since every single company has more than one chemical supplier. The field research was conducted from 2 April 2018 to 10 August 2018. The questionnaires were sent to all companies and followed by face-to-face interviews. According to Loehlin and Beaujean (2017), the minimum total sample is 200. The total number of questionnaires collected is 272 , three of them being rejected. Hence, the final questionnaires amounted to 269. Communication and the relationship between the buyer and the seller in a B2B setting is achieved by specific members of both companies (Hollyoake, 2009; Mummalaneni, 1987). Marketing activities relate to other activities from other departments (Cravens \& Piercy, 2013). The relationship involves people from different departments, such as production, quality control, logistics, sales, and finance at various levels.

\subsection{Model testing}

The research is conducted using a quantitative method with the following steps: beginning with the overall model fit, and the measurement model fit and structural model fit. The data analysis method is meant to ensure that the developed model fits the field data (Wijanto, 2015). The procedure starts with an overall model fit, then continues with the measurement of the model fit, and finally, finishes by estimating the structural model fit. The hypothesis is verified using structural equation model (SEM) with the Lisrel 8.80 software. The first step of the model testing is the overall model fi. All parameter test results surpass the standard (Table 1), so the model is a good fit and is acceptable (Hair, Black, Babin, \& Anderson, 2010). RMSEA is most commonly used to avoid sample size issues and anticipates the missing standard of Chisquare with a close fit standard of RMSEA $<0.05$ and a good fit standard of RMSEA $<0.08$ (Brown \& Cudeck, 1993). The measurement of goodness of fit (NFI, NNFI, CFI, IFI, and RPI) uses the minimum threshold of 0.90; the goodness of fit $>0.90$ indicates good fitness between the data and the model (Wijanto, 2015). These results pass the minimum threshold meaning the model is a good fit (Table 1). 
Table 1. Overall Model Fit

\begin{tabular}{|c|c|c|c|c|}
\hline No & Goodness of Fit & Standard & Result & Remark \\
\hline 1 & RMSEA: Root Mean Square Error of Approximation & $0.05<$ RMSEA $\leq 0.08$ & 0.059 & Good fit \\
\hline 2 & NFI: Normed Fit Index & $\geq 0.90$ & 0.95 & Good fit \\
\hline 3 & NNFI: Non - Normed Fit Index & $\geq 0.90$ & 0.97 & Good fit \\
\hline 4 & PNFI: Parsimonious Normed Fit Index & the higher, the better & 0.87 & \\
\hline 5 & CFI: Comparative Fit Index & $\geq 0.90$ & 0.98 & Good fit \\
\hline 6 & IFI: Incremental Fit Index & $\geq 0.90$ & 0.98 & Good fit \\
\hline 7 & RFI: Relative Fit Index & $\geq 0.90$ & 0.95 & Good fit \\
\hline
\end{tabular}

$90 \%$ confident interval for RMSEA=0.056-0.062 and p-value (close fit RMSEA $<0.05)=0.00$

The second step of the model testing is to determine the measurement model fit toward the 20 indicators. The measurement of each indicator uses the standard of 0.50 as a minimum prerequisite threshold (Hair et. al., 2010), to ensure that all indicators are valid. An indicator is valid with a factor loading of $\geq 0.50$ and tvalue of $\geq 1.96$. This measures all the coefficients between the constructs with a minimum threshold of 0.05 and a t-test value of $>1.96$ (Igbaria, Zinatelli, Cragg, \& Cavaye, 1997). All of the indicators are valid and contribute to their constructs significantly as reflected by Table 2 .

Table 2. Factor Loadings and T-value

\begin{tabular}{|c|c|c|c|c|c|}
\hline Variables & \multicolumn{2}{|c|}{ Indicators } & Lambda & t-value & Remark \\
\hline Switching Cost (SC) & SC1 & Additional cost & 0.75 & 14.35 & Valid \\
& SC2 & Creates a new job & 0.90 & 18.74 & Valid \\
& SC3 & Product quality risks & 0.84 & 16.77 & Valid \\
& SC4 & Uncomfortable work & 0.81 & 15.71 & Valid \\
& SC5 & Less finance support & 0.58 & 10.51 & Valid \\
\hline Satisfaction (Sat) & CS1 & Good product quality and service & 0.87 & & Valid \\
& CS2 & Good relationship & 0.90 & 21.47 & Valid \\
& CS3 & Fair treatment & 0.77 & 15.88 & Valid \\
& CS4 & A good performance in general & 0.78 & 16.21 & Valid \\
& CS5 & Helpfulness & 0.79 & 16.70 & Valid \\
\hline Commitment (Com) & Com1 & Benefit with the relationship & 0.81 & & Valid \\
& Com2 & We care the relationship & 0.89 & 19.13 & Valid \\
& Com3 & We keep the relationship & 0.83 & 15.38 & Valid \\
& Com4 & We develop the relationship. & 0.75 & 13.30 & Valid \\
& Com5 & We keep the relationship forever. & 0.60 & 10.59 & Valid \\
\hline Loyalty (Loy) & Loy1 & Repurchase the existing product & 0.76 & & Valid \\
& Loy2 & Repurchase with more quantity. & 0.79 & 14.17 & Valid \\
& Loy3 & Purchase another type of product & 0.77 & 12.31 & Valid \\
& Loy4 & We put this supplier as top priority & 0.80 & 12.89 & Valid \\
& Loy5 & We will recommend this supplier & 0.66 & 10.40 & Valid \\
\hline
\end{tabular}

Note: All items are collected and bundled using top and bottom two boxes first. The cluster data are measured by using 5 -point Likert scale, which is the anchors $1=$ fully disagree and $5=$ fully agree.

Table 3. Construct Reliability (CR) and Average Variance Extracted (VE)

\begin{tabular}{|c|c|c|c|c|}
\hline No & Latent Variable & Symbol & AVE & CR \\
\hline 1 & Switching Cost & SC & 0.614 & 0.886 \\
\hline 2 & Satisfaction & CS & 0.678 & 0.913 \\
\hline 3 & Commitment & Com & 0.612 & 0.886 \\
\hline 4 & Loyalty & Loy & 0.574 & 0.870 \\
\hline
\end{tabular}


Based on Hair et. al. (2010), a minimum threshold of average variance extractive 0.50 (AVE) for each construct indicates a favorable discriminant validity of each construct. Furthermore, the minimum threshold of construct reliability $0.70(\mathrm{CR})$ indicates the reliability and consistency of the measurement indicators (Hair et. al., 2010). Table 3 shows that every construct passes the minimum threshold.

Table 4. Correlation Matrix: Squared Inter-construct Correlations

\begin{tabular}{|c|c|c|c|c|}
\hline Items & Switching C & Satisfaction & Commitment & Loyalty \\
\hline Switching Cost & 1.00 & & & \\
\hline Satisfaction & 0.39 & 1.00 & & \\
\hline Commitment & 0.38 & 0.92 & 1.00 & \\
\hline Loyalty & 0.58 & 0.64 & 0.67 & 1.00 \\
\hline
\end{tabular}

Note: Correlations coefficients being significant at $\geq .05$-level and marked with an asterisk

In this paper, the author also analyzes the correlation between the constructs as shown in Table 4 . All of the coefficients among the constructs are positive and indicate that the measured constructs are correlated. All construct correlations are below the self-correlation coefficient (1.0) indicating that all constructs are correlated positively and valid with the strongest correlation shown between satisfaction and commitment.

\section{Results}

In the final step of the model testing, the author conducts a structural model fit. In the analysis of the structural model, all hypotheses are verified by the estimated coefficient and t-value for significant status.

Table 5. Structural Model Coefficient and T-value

\begin{tabular}{|c|c|c|c|c|c|}
\hline No & Pathline & Hypothesis & Coefficient & t-value & Conclusion \\
\hline 1 & Commitment $\rightarrow$ Loyalty & H1 & 0.54 & 3.05 & Supported \\
\hline 2 & Satisfaction $\rightarrow$ Loyalty & H2 & -0.07 & -0.36 & Rejected \\
\hline 3 & Satisfaction $\rightarrow$ Commitment & H3 & 0.85 & 7.80 & Supported \\
\hline 4 & Switching Cost $\rightarrow$ Loyalty & H4 & 0.22 & 3.74 & Supported \\
\hline
\end{tabular}

Note: Coefficient that are significant at the .05 or lower level (one-tailed) are in bold

From Table 5, it can be seen that the path coefficient of satisfaction - loyalty $(-0.07$ and t-value -0.36$)$ indicates that satisfaction does not influence loyalty directly meaning $\mathrm{H} 2$ is not supported. The results suggest that customer satisfaction in the chemical market will not encourage a customer to become a loyal customer instantaneously. The path coefficient of satisfaction-commitment (0.85 and t-value 7.80) indicates that satisfaction has a significant influence on commitment meaning that $\mathrm{H} 3$ is supported. Hence, as long as the customers are satisfied, a customer will remain loyal to chemical suppliers. At this stage, the customer has not become a loyal customer yet; the customer has not put the chemical supplier as the first preference over other alternatives. The further step with the path coefficient of commitment-loyalty $(0.54$ and t-value 3.05) indicates that commitment influences loyalty directly and significantly thereby supporting H1. Figure 1 shows the coefficient between the constructs. 


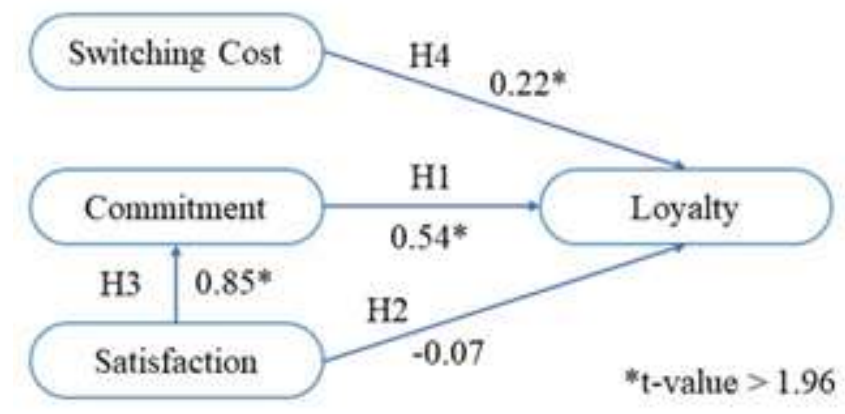

Figure 1. The Proposed Model and Path Coefficient

Table 6. Total Effect

\begin{tabular}{|c|c|c|c|c|}
\hline Constructs & Switching Cost & Satisfaction & Commitment & Loyalty \\
\hline Commitment & & 0.85 & - & - \\
& & $(0.08)$ & & \\
& & 7.80 & & \\
\hline Loyalty & $\mathbf{0 . 2 2}$ & $\mathbf{0 . 3 8}$ & $\mathbf{0 . 5 4}$ & - \\
& $(0.06)$ & $(0.10)$ & $(0.18)$ & \\
& 3.47 & 4.02 & 3.05 & \\
\hline
\end{tabular}

Note: coefficient that are significant at the .05 or lower level (one tail) are in bold

Table 6 shows that satisfaction has an indirect influence on loyalty, with a total effect of 0.38 and a t-value of 4.02. This indicates that customers need a process to be a loyal customer. The path of satisfactioncommitment-loyalty indicates that satisfaction has a direct influence on loyalty, with commitment as an intermediate variable. The path coefficient of switching costs-loyalty ( 0.22 and t-value 3.47$)$ indicates that switching costs has a positive influence on loyalty thereby supporting $\mathrm{H} 4$.

As $\mathrm{H} 2$ is rejected, satisfaction needs a mediating variable, such as commitment, to achieve customer loyalty. The final model is adjusted as reflected at Figure 2. The final model identifies the path model of all constructs that influence loyalty, either directly or indirectly.

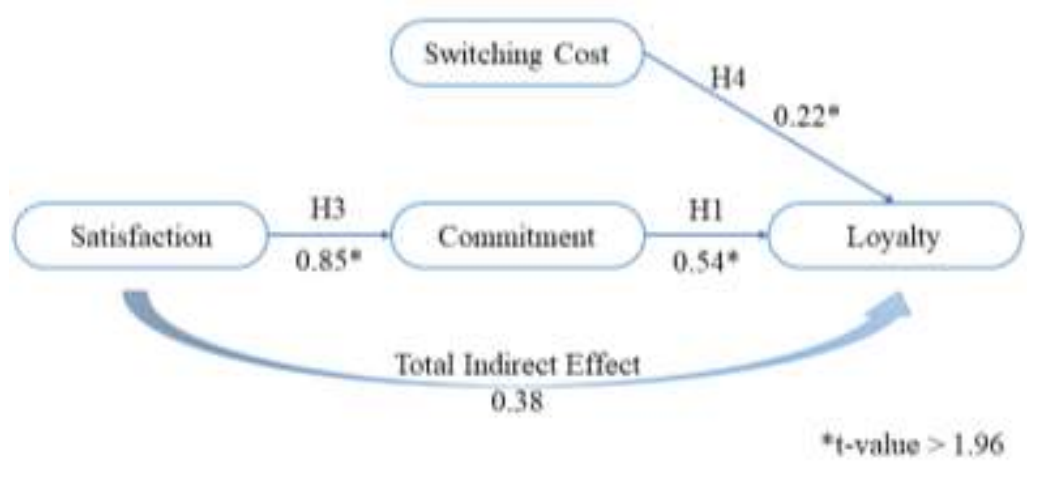

Figure 2 Adjusted and Final Model

\section{Discussion}

This study aims to answer the following questions: What is the most influential factor on customer loyalty in the chemical market? and Is switching costs the most influential factor influencing final purchasing decisions of customers? The author conducted a deep analysis of the link and correlations among the 
constructs. The contributions deliver the relational insight among the constructs, including the construct that has the most direct influence on customer loyalty (commitment, coefficient: $0.54, \mathrm{t}$ - value 3.05 ) and the construct for which one must achieve customer loyalty using commitment as a mediator (satisfaction, total effect: 0.38 , t-value 4.02). This study identifies an inconsistency in the satisfaction-loyalty path (coefficient: $0.07, \mathrm{t}$-value -0.36) which indicates the time for customers to process their decision on loyalty. The first major contribution of the study is the final model and correlation in the business context, which confirms the importance of commitment and satisfaction, compared to switching costs (coefficient: $0.22 \mathrm{t}$-value 3.74) to achieve customer loyalty in the chemical market. From the model, the findings on the satisfactioncommitment-loyalty link suggest that the chemical industry should enhance satisfaction because of the positive correlation between satisfaction and commitment.

The second contribution of the study is an uncorrelated satisfaction-loyalty path. $\mathrm{H} 2$ is rejected in this study meaning that satisfaction does not have a direct influence on loyalty. In the interviews with the respondents, the buyer was really concerned with the consistency of product quality. With reference to the satisfaction indicators, the chemical industry must deliver performance in terms of product quality and services, consistency, fair customer treatment, and overall positive performance. Based on these satisfaction indicators, the seller must make enough effort to achieve customer satisfaction. Hence, the achievement of customer loyalty takes time.

From the study of the post purchase process, a satisfactory purchase experience is a crucial prerequisite to repeat purchases or customer loyalty (Kearney et. al., 2017; Oliver, 1993). In this business context, commitment should be used as a mediator to achieve customer loyalty. Referring to the concept of loyalty by Oliver (1999), loyalty starts with cognitive loyalty, followed by affective and conative loyalty, ending with action loyalty. These concepts are able to explain the satisfaction-commitment-loyalty path as a sequence process. Since this research relates to a tailor made - chemical product (custom and not-commodity), consistency of output becomes a crucial issue. The buyer needs time to process and evaluate output consistency following the initial transaction. The evaluation occurs after the purchase is made and is a very important factor to determine further loyalty by the customer. Another commitment concept supporting the findings of this study is the three dimensions of commitment: input, attitudinal and temporal. Input consists of custom products and dedicated research of chemical product formulation for specific buyers. Attitudinal refers to the long-term commitment of a buyer, since a seller has invested expertise, expenses and equipment. The temporal dimension is measured by actual inputs made in future exchange (Gundlach et. al., 1995). From this concept, it is clear that commitment leads to loyalty.

The third contribution of the paper relates to the influence of switching costs in the chemical market. Switching costs has a direct and positive influence on loyalty (coefficient: $0.22 \mathrm{t}$-value 3.74 ) however the influence itself is relatively lowest compared to the other correlations. This means that switching from existing suppliers to alternatives would be costly, takes time, and results in increased costs and lost opportunities. However, chemical markets will continue to switch to alternatives if the products and services they receive do not meet their expectations.

\section{Conclusion}

Based on the data gathered in this study, the author makes some critical conclusions. First, the wood industry believes commitment and satisfaction are more than switching costs. The justification of this finding lies in the fact that unless the wood industry in Indonesia loses the confidence of its customers, the wood industry will remain with its' existing chemical suppliers. These finding answer the research question and suggests that switching costs is not an appropriate tactical step to achieve customer loyalty. Second, the wood industry respects the commitment of both sides since the customer gets the benefit from the supplier (for instance, tailor made products, logistic tank support from chemical suppliers, and financial support). The wood industry takes time to evaluate chemical supplier performance; hence it takes time to achieve customer loyalty. 
The justification for the second finding is the issue of consistency in chemical quality. The wood industry considers quality consistency a top priority. It is commonly accepted that it takes time for the wood industry to achieve customer loyalty. This is why satisfaction does not influence customer loyalty in the wood industry. These findings suggest that there is a need to monitor and control all factors related to chemical quality consistency such as, material quality, production process, formulation, quality control and equipment maintenance.

This empirical study has a few limitations that offer opportunities for further research. First, the industry of the research object focuses on wood based and related wood industry only. Since the respondent's industries are specific, this study will achieve a more precise result. The findings may be generalized to a similar chemical industry in a similar business context. On the other hand, the results may also limit the generalization of the finding. Future studies may extend the research to other industries. Second, this empirical study focuses on a custom product; it would be beneficial to conduct further research on other products for a deeper understanding.

\section{References}

Anderson, E. W. (1994). Cross-category variation in customer satisfaction and retention. Marketing Letters, 5(1), 1930. https://doi.org/10.1007/BF00993955

Anderson, E. W., Fornell, C., \& Lehmann, D. R. (1994). Customer satisfaction, market share, and profitability: findings from Sweden. Journal of Marketing, 58(July), 53-66. https://doi.org/10.2307/1252310

Anderson, E. W., \& Sullivan, M. W. (1993). The antecedents and consequences of customer satisfaction for firms. Marketing Science, 12(2), 125-143. https://doi.org/10.1287/mksc.12.2.125

Anderson, E., \& Weitz, B. (1992). The use of pledges to build and sustain commitment in distribution channels. Journal of Marketing Research, 29(1), 18. https://doi.org/10.2307/3172490

Askariazad, M. H., \& Babakhani, N. (2015). An application of European Customer Satisfaction Index (ECSI) in Business to Business (B2B) context. Journal of Business and Industrial Marketing, 30(1), 17-31. https://doi.org/10.1108/JBIM-07-2011-0093

Barroso, C., \& Picón, A. (2012). Multi-dimensional analysis of perceived switching costs. Industrial Marketing Management, 41(3), 531-543. https://doi.org/10.1016/j.indmarman.2011.06.020

Bendapudi, N., \& Berry, L. L. (1997). Customers' motivations for maintaining relationships with service providers. Journal of Retailing, 73(1), 15-37. https://doi.org/10.1016/S0022-4359(97)90013-0

Biedenbach, G., Bengtsson, M., \& Marell, A. (2015). Brand equity, satisfaction, and switching costs: An examination of effects in the business-to-business setting. Marketing Intelligence and Planning, 33(2), 164-178. https://doi.org/10.1108/mip-03-2014-0059

Blut, M., Beatty, S. E., Evanschitzky, H., \& Brock, C. (2014). The impact of service characteristics on the switching costs-customer loyalty link. Journal of Retailing, 90(2), 275-290. https://doi.org/10.1016/j.jretai.2014.04.003

Blut, M., Frennea, C. M., Mittal, V., \& Mothersbaugh, D. L. (2015). How procedural, financial and relational switching costs affect customer satisfaction, repurchase intentions, and repurchase behavior: A meta-analysis. International Journal of Research in Marketing, 32(2), 226-229. https://doi.org/10.1016/j.ijresmar.2015.01.001

Bolton, R. N., \& Drew, J. H. (1991). Multistage model of service customers' quality and value assessments. Journal of Consumer Research, 17(4), 375-384. https://doi.org/10.1017/CBO9781107415324.004

Borg, S. W., \& Johnston, W. J. (2013). The IPS-EQ Model: interpersonal skills and emotional intelligence in a sales process. Journal of Personal Selling \& Sales Management, 33(1), 39-52. https://doi.org/10.2753/PSS0885-3134330104

Briggs, E., Landry, T. D., \& Daugherty, P. J. (2007). Patronage in continually delivered business service contexts. Journal of Business Research, 60(11), 1144-1151. https://doi.org/10.1016/j.jbusres.2007.04.005

Brown, M., \& Cudeck, R. (1993). EQS Structural Equations Program Manual. Los Angeles (US): Multivariate Software Inc.

Caceres, R. C., \& Paparoidamis, N. G. (2007). Service quality, relationship satisfaction, trust, commitment and business-to-business loyalty. European Journal of Marketing, 41(7/8), 836-867. https://doi.org/10.1108/03090560710752429

Carmine, E. G., \& Zeller, R. (1979). Reliability and Validity Assessment. Newbury Park, CA (US): Sage Publications. 
Cravens, D. W., \& Piercy, N. F. (2013). Strategic Marketing (10th ed.). New York (US): McGraw-Hill International Edition.

Dick, A. S., \& Basu, K. (1994). Customer loyalty: Toward an integrated conceptual framework. Journal of the Academy of Marketing Science, 22(2), 99-113. https://doi.org/10.1177/0092070394222001

Doney, P. M., \& Cannon, J. P. (1997). An Examination of the Nature of Trust in Buyer-Seller Relationships. Journal of Marketing, 61(2), 35-51. https://doi.org/10.2307/1251829

Fornell, C. (1992). A national customer satisfaction barometer: The Swedish experience. Journal of Marketing, 56(1), 6. https://doi.org/10.2307/1252129

Fournier, S., \& Mick, D. G. (1999). Rediscovering Satisfaction. Journal of Marketing, 63(4), 5-23. https://doi.org/10.2307/1251971

Fullerton, G. (2011). Creating advocates: the roles of satisfaction, trust and commitment. Journal of Retailing and Consumer Services, 18(1), 92-100. https://doi.org/10.1016/j.jretconser.2010.10.003

Gil-Saura, I., Frasquet-Deltoro, M., \& Cervera-Taulet, A. (2009). The value of B2B relationships. Industrial Management \& Data Systems, 109(5), 593-609. https://doi.org/10.1108/02635570910957605

Gundlach, G. T., Achrol, R. S., \& Mentzer, J. T. (1995). The structure of commitment in exchange. Journal of Marketing, 59(1), 78-92. https://doi.org/10.2307/1252016

Hair, J. F., Black, W. C., Babin, B. J., \& Anderson, R. E. (2010). Multivariate Data Analysis. Pearson-Prentice Hall, NJ. Hollyoake, M. (2009). The four pillars: Developing a 'bonded' business-to-business customer experience. Journal of Database Marketing \& Customer Strategy Management, 16(2), 132-158. https://doi.org/10.1057/dbm.2009.14

Hunt, S. D., \& Morgan, R. M. (1994). Relationship marketing in the era of network competition. Marketing Management, 3(1), 18-28. Retrieved from https://search.proquest.com/docview/194215893?accountid=32819

Igbaria, M., Zinatelli, N., Cragg, P., \& Cavaye, A. L. M. (1997). Personal computing acceptance factors in small firms: a structural equation model. MIS Quarterly. https://doi.org/10.2307/249498

Jones, M. A., Reynolds, K. E., Mothersbaugh, D. L., \& Beatty, S. E. (2007). The positive and negative effects of switching costs on relational outcomes. Journal of Service Research, 9(4), 335-355. https://doi.org/10.1177/1094670507299382

Kadic-Maglajlic, S., Vida, I., Obadia, C., \& Plank, R. (2016). Clarifying the influence of emotional intelligence on salesperson performance. Journal of Business and Industrial Marketing, 31(7), 877-888. https://doi.org/10.1108/JBIM09-2015-0168

Kearney, T., Walsh, G., Barnett, W., Gong, T., Schwabe, M., \& Ifie, K. (2017). Emotional intelligence in frontline/back-office employee relationships. Journal of Services Marketing, 31(2), 185-199. https://doi.org/10.1108/JSM09-2016-0339

Kemp, E. A., Borders, A. L., Anaza, N. A., \& Johnston, W. J. (2018). The heart in organizational buying: marketers' understanding of emotions and decision-making of buyers. Journal of Business and Industrial Marketing, 33(1), $19-28$. https://doi.org/10.1108/JBIM-06-2017-0129

Lam, S. Y., Shankar, V., Erramilli, M. K., \& Murthy, B. (2004). Customer value, satisfaction, loyalty, and switching costs: An illustration from a business-to-business service context. Journal of the Academy of Marketing Science, 32(3), 293-311. https://doi.org/10.1177/0092070304263330

Loehlin, J. C., \& Beaujean, A. A. (2017). Latent variable models: an introduction to factor, path, and structural equation analysis (5th ed.). New York (US): Taylor \& Francis. https://doi.org/10.4324/9781315643199

Maute, M. F., \& Forrester, W. R. (1993). The structure and determinants of consumer complaint intentions and behavior. Journal of Economic Psychology, 14(2), 219-247. https://doi.org/10.1016/0167-4870(93)90001-2

Molinari, L. K., Abratt, R., \& Dion, P. (2008). Satisfaction, quality and value, and effects on repurchase and positive word-of-mouth behavioral intentions in a B2B services context. Journal of Services Marketing, 22(5), 363-373. https://doi.org/10.1108/08876040810889139

Morgan, R. M., \& Hunt, S. D. (1994). The commitment trust-theory of relationship marketing. Journal of Marketing. https://doi.org/10.2307/1252308

Mummalaneni, V. (1987). The influence of a close personal relationship between the buyer and the seller on the continued stability of their role relationship. The Pennsylvania State University.

Oliver, R. L. (1993). Cognitive, affective, and attribute bases of the satisfaction response. Journal of Consumer Research, 20(3), 418. https://doi.org/10.1086/209358

Oliver, R. L. (1999). Whence Consumer Loyalty? Journal of Marketing, 63, 33-44. https://doi.org/10.2307/1252099 
Oliver, R. L., \& DeSarbo, W. S. (1988). Response determinants in satisfaction judgements. Journal of Consumer Research, 14(March), 495-507. https://doi.org/10.1086/209131

Palaima, T., \& Auruškevičiene, V. (2007). Modeling relationship quality in the parcel delivery services market. Baltic Journal of Management, 2(1), 37-554. https://doi.org/10.1108/17465260710720237

Patti, C. H., Hartley, S. W., \& Kennedy, S. L. (1991). Business-to-business Advertising: A Marketing Management Approach. Lincolnwood (US): NTC Business Books.

Rauyruen, P., \& Miller, K. E. (2007). Relationship quality as a predictor of B2B customer loyalty. Journal of Business Research, 60(1), 21-31. https://doi.org/10.1016/j.jbusres.2005.11.006

Russo, I., Confente, I., Gligor, D. M., \& Autry, C. W. (2015). To be or not to be (loyal): Is there a recipe for customer loyalty in the B2B context? Journal of Business Research. https://doi.org/10.1016/j.jbusres.2015.07.002

Rust, R. T., Zeithaml, V. A., \& Lemon, K. N. (2000). Driving Customer Loyalty: How Customer Lifetime Value is Reshaping Corporate Strategy. New York (US): The Free Press, A Division of Simon \& Schuster Inc.

Samudro, A., Sumarwan, U., Yusuf, E. Z. ., \& Simanjuntak, M. (2018). Perceived Value, Social Bond, and Switching Cost as Antecedents and Predictors of Customer Loyalty in the B2B Chemical Industry Context: A Literature Review. International Journal of Marketing Studies, 10(4), 124-138. https://doi.org/10.5539/ijms.v10n4p124

Sanchez-Franco, M. J. (2009). The moderating effects of involvement on the relationships between satisfaction, trust, and commitment in e-banking. Journal of Interactive Marketing, 23, 247-258. https://doi.org/10.1016/j.intmar.2009.04.007

Storbacka, K., Strandvik, T., \& Gronroos, C. (1994). Managing customer relationships for profit: the dynamics of relationship quality. International Journal of Service Industry Management, 5(5), 21-38. https://doi.org/10.1108/09564239410074358

Ulaga, W., \& Eggert, A. (2006). Value-based differentiation in business relationships: Gaining and sustaining key supplier status. Journal of Marketing, 70(1), 119-136. https://doi.org/10.1509/jmkg.2006.70.1.119

Walter, A., Mueller, T. A., \& Helfert, G. (2000). The impact of satisfaction, trust, and relationship value on commitment: Theoretical considerations and empirical results. In IMP Conference Proceedings (pp. 07-09). Bath, United Kingdom. Retrieved from http://www.impgroup.org/uploads/papers/131.pdf

Watson, G. F., Beck, J. T., Henderson, C. M., \& Palmatier, R. W. (2015). Building, measuring, and profiting from customer loyalty. Journal of the Academy of Marketing Science, 43(6), 790-825. https://doi.org/10.1007/s11747-0150439-4

Wijanto, S. H. (2015). Metode Penelitian menggunakan Structural Equation Modelling dengan LISREL 9. Yogyakarta (ID): Grha Ilmu.

Yanamandram, V., \& White, L. (2006). Switching barriers in business-to-business services: a qualitative study. International Journal of Service Industry Management, 17(2), 158-192. https://doi.org/10.1108/09564230610656980 